OPINION PIECE

\title{
Five Reasons Why Working as a Student Partner is Energizing
}

\author{
Maya Jonsson, The Teaching and Learning Institute, Bryn Mawr and Haverford Colleges
}

Contact: themayajonsson@gmail.com

In January of 2019, I assumed the role of student consultant in the Students as Teachers and Learners Program (SaLT) at Bryn Mawr and Haverford Colleges. During my first semester I worked in a one-on-one, classroom-focused partnership with a physics professor, and in my second semester I served as a participant observer in the weekly student partner meetings facilitated by the director of SaLT. In both roles, I found myself thinking about how energizing the partnerships were, not just for myself, but also for other student consultants who, unprompted, told me they felt energized by the work. While I elaborate on my partnership experiences in this short video (https://www.youtube.com/watch?v=p3 4UrU3xrs), here I offer five reasons why, from my perspective, working as a student partner is energizing.

The literature frequently discusses the positive attributes of partnership for students (see Mercer-Mapstone et al., 2017), although "energizing" is not a common descriptor. Why does it matter to experience partnership work as energizing? Sometimes academia can be burdensome and life-draining as students balance the competing pressures of professor expectations, jobs, and extracurricular activities, all within institutions that are not always understanding of individual needs. Therefore, finding spaces that are life-giving and figuring out why the dynamics infuse energy is vital for ensuring student well-being. Partnership work can be emotionally and intellectually demanding at times (see Cook-Sather, Bahti, \& Ntem, 2019), so it was surprising to find that other consultants and I felt more alive, excited, and renewed following our meetings with each other and with faculty partners. Recognizing and naming the energizing aspects of this work can be an intentional part of both facilitating and engaging in partnership. By naming what is energizing, students can be better prepared to figure out and notice how the work is making them feel and how to further cultivate positive emotions within and beyond the work.

In this opinion piece, I offer five reasons for why I find working as a student partner in classroom-focused partnerships energizing. Each points to the attributes of partnership work that stand in contrast to the traditional academic experiences described above. These are based on my own experiences, observations of weekly student consultant meetings facilitated by the SaLT director, and both formal and informal conversations with other SaLT student consultants over the course of a semester. The five reasons are:

- Connecting with other people,

- Receiving/giving affirmation,

- Feeling like you can make change in your community, 
- Having a separate/liminal learning space, and

- Experiencing "aha" moments that have larger implications.

\section{CONNECTING WITH OTHER PEOPLE}

The opportunity to connect with other people-professors as well as fellow students-is a primary reason why this work is so life-giving to me and the consultants I talked with. Developing student-professor relationships built on deep trust, as opposed to the more hierarchal and transactional relationships in much of higher education, feels energizing because it is a manifestation of true connection. Student partner meetings also provide a generative space for building connections. I have personally found myself developing a network of peers who share similar reflective inclinations about classrooms and enjoy informal conversations about teaching and learning. These bonds bring me so much joy, and it is exciting to have people to share these reflections with, even outside of formal consultant meetings.

\section{RECEIVING/GIVING AFFIRMATION}

Affirmation, both giving and receiving it, makes partnership enjoyable and energizing. As suggested by the literature on how partnership enacts positive psychology principles (CookSather et al., 2017), sharing appreciation and positive perceptions produces beneficial intrapersonal and interpersonal consequences beyond that of the effect of the positive event itself, especially when met with affirmative listeners (Gable, Reis, Impett, \& Asher, 2004; Lambert et al., 2012). In traditional institutional spaces, we focus on critique-on what's "wrong" with an argument or a process or an approach. In juxtaposition, our work as consultants is to reflect back to faculty partners our perceptions of what is working well in their teaching as well as what might be refined, and my fellow student consultants have frequently expressed that it feels good to know faculty partners value our opinions and appreciate this.

Sometimes student partners shy away from discussion of affirmation or praise because it seems selfish or egocentric, as I heard expressed in our consultant meetings. It is important, however, for students to know that feeling recognized is valid and central to enacting energizing partnership work. The attention partnership work gives to receiving and giving affirmation makes partnership a positive, life-giving counter-space.

\section{FEELING LIKE YOU CAN MAKE CHANGE IN YOUR COMMUNITY}

One of the most empowering parts of partnership work is feeling like we are making palpable change, which I and other consultants do not always feel in other aspects of student life. One consultant expressed, "I feel like my opinion actually matters," pointing to how partnership work exists in contrast to the almost impossible task of fighting bureaucracyridden, ableist, classist, and racist institutions at a macro-level. In partnership work we can make micro-level changes that have macro-level implications. In my own partnership work I have felt this when working with a faculty member on making class participation more equitable-which represents an immediate change to make marginalized students feel more included.

Making immediate change to create more equitable, inclusive, and positive learning environments while being part of a collective effort, rather than working alone, develops 
feelings of efficacy; it feels life-giving to be part of change-making in solidarity with others. Such feelings of self-efficacy are energizing because they give one a sense of control over one's motivation, action, and social environment (Bandura, 1986)-they reinforce that as individual students we can make change in our classrooms and broader school community.

\section{HAVING A SEPARATE/LIMINAL LEARNING SPACE}

Partnership work, both with faculty and in meetings with fellow student consultants, can feel like it is taking place in a suspended space, apart from the everyday grind of traditional academia-work that one student consultant described as a "separate time than regular life" that "lacks monotony in every way." Learning within SaLT partnerships is not prescribed or measured, and in these liminal spaces we come up with new, helpful ideas that can affect the ways we act and interact in other spaces; we carry ways of being from the "as-if" spaces of partnership beyond partnership (Cook-Sather \& Felten, 2017,p.181).

Additionally, part of what may make this space feel separate and energizing is the way in which traditional power structures and roles are subverted in the partnership work fellow consultants and myself have experienced. As Dwyer (2018) discusses, genuine partnership happens when students, staff, and academic leaders are in conversation together about goals and roles, shirking traditional hierarchy and creating a space where participants are not bound by their normal positions. Part of what is energizing about this liminal space is the excitement of being able to work in a different capacity, to feel an equal participant in discussions about university life and classroom culture.

\section{EXPERIENCING "AHA" MOMENTS THAT HAVE LARGER IMPLICATIONS}

Partnerships give us the time and space to experience frequent "aha" moments, both with faculty and fellow consultants. "Aha" moments are characterized by a feeling of sudden discovery or understanding, a moment when everything clicks. They may center around understanding the mechanism behind a classroom dynamic, figuring out a technique to create a more equitable learning experience, or having macro-level revelations about teaching and learning. Sometimes it takes immense effort to grapple with understanding a specific classroom dynamic or parsing out potential pedagogical solutions to classroom challenges, and so finally coming to an understanding, especially when with others, can feel exhilarating.

The listening involved in partnership work, so rare in fast-paced university environments, may in part prompt these "aha" moments. When we take the time to create spaces of shared reflection with others, we may come to revelations that have been evading us due to a lack of time to reflect in honest ways. This exciting spark of understanding can even carry over into other learning contexts. Some "aha" moments may center around reflecting on personal growth, and I have found that partnership has given me the space to reflect on and realize my development in skills of collaboration, analyzing group dynamics, and presenting feedback. It is energizing to come to these sudden realizations about oneself and celebrate that growth with others. 


\section{CONCLUSION}

Considering what makes partnership work energizing is important to recognize and celebrate, so we can actively work to notice and cultivate this feeling more. This matters because work that feels uplifting, exciting, and life-giving is intrinsically valuable. Additionally, it has important implications for making partnership work emotionally and intellectually sustainable for students and faculty by making the work enjoyable and potentially beneficial to overall well-being. In my own experiences, and that of other consultants, it also seems that much of what made the work energizing stood in contrast to our traditional academic experiences and relationships, making it a potentially important counter-space. While research has documented the benefits of partnership (e.g., Mercer-Mapstone et al., 2017), future inquiry that reveals the ways in which partnership work in institutions can be draining as well as energizing will help those engaged in partnership strive to support the latter.

\section{ACKNOWLEDGEMENTS}

I would like to acknowledge and say thank you to Dr. Alison Cook-Sather (Bryn Mawr and Haverford Colleges) for her guidance and help with this piece, as well as for creating the space for me to explore this topic within our unique partnership. I would also like to thank all of the student consultants who I spoke with both formally and informally to better understand what about this work is so energizing to us.

\section{NOTES ON CONTRIBUTOR}

Maya Jonsson is a recent graduate of Bryn Mawr College with a degree in political science and education. She is currently pursuing her M.S.Ed. in secondary social studies education at the University of Pennsylvania.

\section{REFERENCES}

Bandura, A. (1986). Social foundations of thought and action: A social cognitive theory. Englewood Cliffs, NJ: Prentice-Hall.

Cook-Sather, A., Ntem, A., \& Bahti, M. (2019). Pedagogical partnerships: A how-to guide for faculty, students, and academic developers in higher education. Center for Engaged Learning, Elon University: Open-Access Series. Retrieved from http://www.centerforengagedlearning.org/wp-content/uploads/2019/12/pedagogicalpartnerships.pdf

Cook-Sather, A., \& Felten, P. (2017). Ethics of academic leadership: Guiding learning and teaching. In F. Wu \& M. Wood (Eds.), Cosmopolitan perspectives on becoming an academic leader in higher education (pp. 175-191). London: Bloomsbury Academic.

Cook-Sather, A., Schlosser, J., Sweeney, A., Peterson, L., Cassidy, K., \& Colon-Garcia, A. (2017). The pedagogical benefits of enacting positive psychology practices through a studentfaculty partnership approach to academic development. International Journal for Academic Development, 23(2), 123-134. https://doi.org/10.1080/1360144X.2017.1401539 
Dwyer, A. (2018). Toward the formation of genuine partnership spaces. International Journal for Students as Partners, 2(1), 11-15. https://doi.org/10.15173/ijsap.v2i1.3503

Gable, S. L., Reis, H. T., Impett, E., \& Asher, E. R. (2004). What do you do when things go right? The intrapersonal and interpersonal benefits of sharing positive events. Journal of Personality and Social Psychology, 87(2), 228-245. https://doi.org/10.1037/0022$\underline{3514.87 .2 .228}$

Lambert, N. M., Gwinn, M. A., Baumeister, R. F., Strachman, A., Washburn, I. J., Gable, S. L., \& Fincham, F. D. (2012). A boost of positive affect: The perks of sharing positive experiences. Journal of Social and Personal Relationships, 30(1), 24-43. https://doi.org/10.1177/0265407512449400

Mercer-Mapstone, L., Matthews, K. E., Dvorakova, S. L., Abbot, S., Cheng, B., Felten, P., Knorr, K., Marquis, E., Rafaella, S., \& Swaim, K. (2017). A systematic literature review of students as partners in higher education. International Journal for Students as Partners, 1(1). https://doi.org/10.15173/ijsap.v1i1.3119 